\begin{tabular}{|l|l|l||}
\hline \multicolumn{2}{|c|}{ PublisherInfo } \\
\hline \hline PublisherName & $:$ & BioMed Central \\
\hline \hline PublisherLocation & $:$ & London \\
\hline \hline PublisherImprintName & $:$ & BioMed Central \\
\hline \hline
\end{tabular}

\title{
Metastatic medulloblastoma
}

\begin{tabular}{|l|l|l||}
\hline \multicolumn{2}{|c|}{ ArticleInfo } \\
\hline \hline ArticleID & $:$ & 4198 \\
\hline \hline ArticleDOI & $:$ & $10.1186 /$ gb-spotlight-20010911-01 \\
\hline \hline ArticleCitationID & $:$ & spotlight-20010911-01 \\
\hline \hline ArticleSequenceNumber & $:$ & 269 \\
\hline \hline ArticleCategory & $:$ & Research news \\
\hline \hline ArticleFirstPage & $:$ & 1 \\
\hline \hline ArticleLastPage & $:$ & 2 \\
\hline \hline & & RegistrationDate : 2001-09-11 \\
ArticleHistory & $:$ & OnlineDate $2001-09-11$ \\
\hline \hline ArticleCopyright & $:$ & BioMed Central Ltd2001 \\
\hline \hline ArticleGrants & $:$ & \\
\hline \hline ArticleContext & $:$ & 130592211 \\
\hline \hline
\end{tabular}




\section{Jonathan B Weitzman}

Email: jonathanweitzman@hotmail.com

Medulloblastoma is the most common malignant brain cancer in children. In the Advanced Online Publication of Nature Genetics, Tobey MacDonald and colleagues from the Children's National Medical Center, Washington, DC, report the use of oligonucleotide expression profiling (Affymetrix G110 cancer arrays) to define a set of genes that are prognostic for medulloblastoma metastasis (DOI:10.1038/ ng731). They analysed 23 primary medulloblastomas that were either metastatic $(\mathrm{M}+)$ or non-metastatic (M0) and identified 85 genes that served for class prediction (59 genes were upregulated in metastatic tumours and 26 were decreased). This gene set could assign blinded tumour samples with high accuracy, and the set includes genes for the platelet-derived growth factor receptor alpha (PDGFRA) and components of the Ras/MAP kinase signalling pathway. MacDonald et al. provide additional functional evidence that PDGF and MAP kinase signalling events are important for medulloblastoma cell migration in vitro and propose that specific inhibitors of these signalling pathways may have therapeutic benefits.

\section{References}

1. Medulloblastoma.

2. Nature Genetics, [http://genetics.nature.com]

3. Children's Research Institute, [http://www.cnmcresearch.org/] 